\title{
Interactive effects of temperature, water, and nitrogen availability on the growth, floral traits, and pollination of white mustard, Sinapis alba
}

\author{
Asma Akter ${ }^{1,2 *}$ \& Jan Klečka ${ }^{1}$ \\ ${ }^{1}$ Institute of Entomology, Biology Centre of the Czech Academy of Sciences, České \\ Budějovice, Czech Republic \\ ${ }^{2}$ Department of Zoology, Faculty of Science, University of South Bohemia, České \\ Budějovice, Czech Republic \\ *Corresponding author
}

\begin{abstract}
- Climate change is likely to have a complex effect on the growth of plants, their phenology, plant-pollinator interactions, and reproductive success. Therefore, we tested the impact of three key factors (temperature, water, and nitrogen supply) on traits, pollination, and seed production in Sinapis alba (Brassicaceae).

- We grew the plants in different combinations of temperature, water, and nitrogen supplementation, measured multiple vegetative and floral traits, and assessed the response of pollinators in the field. We also evaluated the effect of growing conditions on seed set in plants exposed to pollinators and hand-pollinated plants.

- Our results show that water stress impaired vegetative growth, decreased flower production, reduced visitation by pollinators and seed set, while nitrogen availability played an important role in nectar production. Temperature modulated the effect of water and nitrogen availability on vegetative and floral traits and strongly affected flowering phenology and flower production.

- We demonstrated that changes in temperature, water, and nitrogen availability induce changes in plant vegetative and floral traits which impact flower visitation and consequently plant reproduction. Climate change, particularly increasing temperature combined with reduced precipitation, thus may impact plant-pollinator interactions with negative consequences for reproduction of wild plants and insect-pollinated crops.
\end{abstract}

Key words: climate change, crop pollination, functional traits, global warming, pollination, seed production, self-incompatibility, Sinapis alba 


\section{Introduction}

Ecosystems worldwide are facing accelerating climate change characterised by increasing temperature and changing levels of precipitations, coupled with $\mathrm{N}_{2}$ deposition, biological invasions, and habitat loss (Hoover et al., 2012). These changes directly affect the development and reproduction of wild plants as well as crops. Studies on plant response to this changing environment serve a great purpose in understanding both agriculture and natural ecosystems and the potential impacts of climatic changing drivers on plant and ecosystem function (Rustad, 2008). For pollinator-dependent plants, changes of these factors may also impact their relationship with pollinators and consequently the success of pollination and plant reproduction (Scaven \& Rafferty, 2013; Gérard et al., 2020). Reproductive success of animal-pollinated plants generally depends on floral traits, which act as an advertisement of reward to their pollinators (Hegland \& Totland, 2005; Basnett et al., 2019). Pollinators are typically attracted by large, showy floral displays providing a large amount of nectar, along with other preferable morphological characters (Hodges, 1995; Galen, 1999; Klecka et al., 2018b). Despite the strong selection from pollinators, plant populations naturally show significant variation in their morphological, phenological and floral characters. Some of this variation is the results of heritable genetical differences among the individuals, while the rest of the variation (phenotypic plasticity) is caused by local environmental factors (Holtsford \& Ellstrand, 1992; Gray \& Brady, 2016). Evidently, different environment related growing conditions have affected the physiology of flowering plants in terms of pollen, nectar and flower production (Scaven \& Rafferty, 2013). And, these changing environmental factors may not only alter the morphological and phenological characteristics of plants but also cause changes to their interactions with pollinators (Carrol et al., 2001).

Temperature is a major determinant of the timing of key developmental phases including morphology and phenology (Bahuguna et al., 2015). Different plant species response differently towards the temperature throughout their life cycle and primarily exhibits these responses through the phenological responses, i.e., stages of plant development, flowering phenology etc. (Hatfield \& Prueger, 2015). Plant flowering phenology is characterised by the timing of the onset and duration of flowering, which is sensitive to variable environmental components (Burkle \& Irwin, 2010; Parachnowitsch \& Kessler, 2010). Increasing temperature can directly affect the physiological and phenological growth of plants (Schweiger et al., 2010). Recent increase in average temperatures in the temperate region allows many plants to start to grow and flower earlier, because of shorter winter and higher spring temperatures (Fitter \& Fitter, 2002; Güsewell et al., 2017). There is an increasing amount of evidence that phenological shifts may play an important role in the pollination of animal-pollinated plants (Memmott et al., 2007; Bartomeus et al., 2011; Rafferty \& Ives 2011; Forrest, 2015), but high local biodiversity may buffer against the effects of phenological shifts (Bartomeus et al., 2013). Although, shifting in flowering time in the plants are most pointed out response to climatic changes, but there is also influences of this event on other important traits of many species (Kudo, 1993; Inouye et al., 2002; Perfors et al., 2003), where plant phenological shifts are more visible in early-flowering plants and less in late-flowering species (Kehrberger \& Holzschuh, 2019). Critical response of plants to these changes also include the changes in the 
duration and abundance of flowering which have potentiality to disrupt the ecological relationship among plants, pollinators and other related species (Memmott et.al., 2007).

Increasing temperature may affect not only flowering phenology, but also other aspects of plant growth and development (Descamps et al., 2018). With the average global temperature predicted to increase by $2-3{ }^{\circ} \mathrm{C}$ over the next 30-50 years (IPCC, 2007), extreme temperature events are also going to be more frequent and long-lasting (Meehl et al., 2007). These events could have dramatic consequences on plant growth and development, pollination, and seed production. For example, Lee and Felker, 1992, showed that drier and hotter temperature result into higher number of inflorescence and pod production while can produce shorter inflorescence and reduce nectar production. In addition, Barlow et al., (2013), showed that extreme heat conditions can reduce the grain production, with decreasing the grain maturity period. Because of the sensitivity of plant growth and reproduction to temperature, temperature changes will eventually affect other biological and ecosystem functions connected to the plant performance (Hatfield \& Prueger, 2015).

Water is the most important requirements for plant growth and the main component of maintaining the plant turgid, photosynthesis, transpiration, and transporting and absorbing nutrients (Berdanier \& Klein, 2011; Descamps et al., 2018). Water availability is likely to change as many regions of the world are facing water scarcity and other regions are facing increased precipitation (Christensen et al., 2007). Any changes in the water availability will alternate the processes and lead to altered plant morphological growth, flower, fruit and seed production (Gallagher \& Campbell, 2017). While water availability is an important determinant of plant growth, its effect on floral traits is less clear. Plant with adequate water supplementation may get the better height and floral abundance and may receive more pollinators (Galen, 2000; Carromero \& Hamrick, 2005). Water availability also directly influences the flowering time and duration along with the morphological growth because water plays an important role in nutrient acquisition (Aronson et al., 1992; Bernal et al., 2011; Lasky et al., 2016). In general, decreased water availability causes early phenological growth although this in not universally applicable to every species when reproduction is size and age dependant (Nord \& Lynch, 2009). Effect of the water availability also related to the stages of phenological growth. For example, severe water deficiency in maize delays silking but not anthesis (Blum, 1996). A number of studies showed a positive effect of higher water availability on nectar production (Zimmermann \& Pyke, 1988, Carroll et al., 2001) and also increased nectar sucrose content (Wyatt et al., 1992). On the other hand, lack of water may not only lead to decreased nectar volume, but also to impaired pollen and seed development (Barnabás et al., 2008; Hedhly, 2011; Snider \& Oosterhuis, 2011). The consequences of water stress for flower visitation by insect pollinators have not been well studied, but there is evidence that alteration of floral rewards by water stress may lead to decreased flower visitation (Descamps et al., 2018).

Another important environmental component is Nitrogen $\left(\mathrm{N}_{2}\right)$, an essential plant nutrient and driver of local plant diversity (Bobbink et al., 2010). This is an essential component of plant life cycle and plant biomass production is related to co-function of $\mathrm{N}_{2}$ and water availability (Quemada \& Gabriel, 2016, Chen et al., 2018). With the current $\mathrm{N}_{2}$ emission rate at the global scale, most of the region will have increased atmospheric $\mathrm{N}_{2}$, and Europe and North America 
might be shifted to the plant composition favourable to higher $\mathrm{N}_{2}$ availability in soil (Bobbink et al., 1998; Bobbink et al., 2010). In a plant community, $\mathrm{N}_{2}$ heterogeneity can occur within a few meters and this can directly affect the plant growth and reproduction (Scott-Wendt et al., 1988), possibly including their mutualistic relationship with pollinators. Higher $\mathrm{N}_{2}$ level can enhance plant growth and enable plants to produce floral rewards of higher quality (Gardener \& Gillman, 2001; Burkle \& Irwin, 2009), which can potentially alter pollinator preferences (Gardener \& Gillman, 2002). Furthermore, $\mathrm{N}_{2}$ enrichment can affect the nectar volume, concentration and composition of amino acids in nectar and potentially altering pollinator preferences and foraging behaviour (Inouye \& Waller 1984; Hoover et al., 2012). Different groups of pollinators are attracted to different source of food provided by the flower and flower nectar and pollen appear to be specialized for different groups of pollinators. For example, hummingbirds prefer flowers which have high sucrose/hexose ratios in nectars (Baker \& Baker, 1983). Different studies showed how the changing environmental conditions altered the composition and the quality of nectar and still pollinators attracted to their preferable food sources. Experimental studies showed that many pollinators were able to detect the differences in the composition of sugar component as well as the composition of the amino acid complement while using artificial nectar (Hill \& Pierce, 1989). Mevi-Schütz \& Erhardt (2003) demonstrated that several female butterfly species have shown a clear preference for nectars with high amino acid contents while they were raised on low quality food. Differences in the volume of nectar have also been shown to affect foraging behaviour (Pyke, 1981). Several studies on fruit and vegetable plant species showed that pollinator preferences for the floral resources strongly dependant on the nectar volume or nectar sugar concentration (Jabłoński et al., 1984; Schmidt et al., 2015; Roldán-Serrano \& Guerra-Sanz, 2005). Study on Citrus plants also showed that honeybee visitation is correlated with the nectar volume (Albrigo et al., 2012). These investigations indicated that both quantity and quality of nectar influences floral resource preferences of pollinators.

Given the importance of changing climate and nutrient availability on the plant growth and phenology, it is important to investigate how these factors act interactively, because all these factors are changing simultaneously, e.g. many regions are getting warmer and at the same time drier, which has been only rarely considered in experimental studies. Intraspecific trait variation induced by environmental change, described above, may have an important on the foraging behaviour and fitness of many pollinators. Studying the quality, quantity, and distribution of floral traits and rewards is an approach that develops the understanding of the links between environmental variation, plant growth, and fitness. Trait variation, which is an ultimate consequence of changing climatic condition attracted few investigations thorough the history of pollination research until recently. It is almost recognised that these climatic drivers can alter the plant growth, phenology of flower and nectar quality, so as the response of pollinators towards the affected plant and different phenological responses alter the competitive ability of different species resulting in unpredictable impacts on community structure. Furthermore, seed production is likely to be affected by these changing factors, although very few studies emphasized on this issue. While temperature and water stress during the critical times of seed development can potentially reduce the seed quality, even a small change in the 
weather events can dramatically change the optimal production in the seed production (Hampton et al., 2016; Serhatli \& Yucesan, 2020).

In this study, we examined the interactive impact of three important environmental factors (water availability, $\mathrm{N}_{2}$ deposition, and temperature) on the plant morphological growth and time of flowering, impact on the flower rewards, pollination and seed production. We selected Sinapis alba as our experimental model because; 1) it is an economically important crop, cultivated over a wide geographic range for oil and fodder 2) it can easily be grown in the greenhouse and used in the field observations, 3) it produces enough flower reward to be measured, 4) it is partly self-incompatible, so seed production strongly depends on pollination by insects and. In our study we aimed to answer the following questions: a) What are the interactive effects of water availability, $\mathrm{N}_{2}$ enrichment, and temperature on the vegetative and floral traits of $S$. alba? b) How flower rewards vary depending on growing conditions? c) How does this intraspecific trait variation caused by changing environmental factors affects flower visitation by pollinators, pollination efficacy, and seed production?

\section{Materials and methods}

\section{Growing $S$. alba under variable temperature, water and, $\mathrm{N}_{2}$ conditions in the greenhouse}

S. alba (white mustard) is a rapidly growing annual plant from the Brassicaceae family with short vegetation period. It is one of the earliest naturalized domesticated crops throughout Asia, North Africa and Europe for over thousands of years (Ekanayake et al., 2016). This crop is widely cultivated for seed, oil, fodder, or as a catch crop. Flowers are yellow, produced in an elongated raceme, have four petals, four sepals, and 6 stamens, of which four are long and two are short. Fruit is a pod with usually four seeds but can have up to eight seeds (Jauzein, 2011). A wide range of pollinating insects visits this plant but Apis mellifera, bumble bees and solitary bees are the main pollinators (Flacher et al., 2020).

This experiment was conducted in the greenhouse, where $S$. alba seedlings were grown in winter, early spring and in early summer from 2017-2018, under variable environmental conditions. Plants were grown in three temperature ranges with natural daily fluctuations of the temperature, on average $21^{\circ} \mathrm{C}$ (winter 2017-2018), $25^{\circ} \mathrm{C}$ (spring 2017), and $29^{\circ} \mathrm{C}$ (summer 2018). A minimum 12 hours of daylight (natural daylight + artificial light) was maintained for all the seasons, where plants grown in the summer received the highest 16 hours of daylight. The plants were grown in a combination of garden soil: compost soil: sand $=2: 2: 1$. Seeds were germinated in germination trays and seedlings were transferred to individual pots $(11 \mathrm{~cm} \times 11 \mathrm{~cm} \times 11 \mathrm{~cm})$ after four days. We divided the seedlings from each temperature regime into four groups which received a different combination of two water levels and two levels of $\mathrm{N}_{2}$ application. Based on the average $\sim 700 \mathrm{~cm}$ precipitation rate in the Central European Region, we determined the lower level of water as $20 \mathrm{ml}$ and the higher level of water as $40 \mathrm{ml} . \mathrm{N}_{2}$ application rate was determined by the estimated rate of $\mathrm{N}_{2}$ deposition within Europe and ideal $\mathrm{N}_{2}$ fertilizer Urea application in the agricultural field for S. alba. $\mathrm{N}_{2}$ was applied once a week for 8 weeks as $0.242 \mathrm{~g} /$ pot as higher level of application 
and $0.121 \mathrm{~g} /$ pot as lower application. Before conducting the main experiment, we performed a preliminary trial to determine the described water level, $\mathrm{N}_{2}$ application, and soil mixture to optimize the growth conditions for $S$. alba. The position of plants in the greenhouse was altered regularly to avoid any possible impact of environmental gradients, e.g. the light level, with the greenhouse.

\section{Assessment of plant morphology, phenology and nectar production}

Growth stages, plant height, and leaf number of each plant were measured regularly for every treatment. Plant height and leaf number were measured several times throughout the growing period and final height was taken after the end of flowering. The number of leaves was counted for the main shoot only. Diameter of each plant was taken at the point of $20 \mathrm{~cm}$ height. The number of days until the onset of flowering was counted from the day of the seedling transfer to the opening of first flower and the total number of flowers bloomed were counted until the end of flowering. Nectar was collected from 4 flowers per plant in each treatment group after one day of flowering by using calibrated $0.5 \mu$ l Capillary tubes Drummond Microcaps ${ }^{\circledR}$, which allowed us to measure the volume of nectar. Additional data were collected on the plant fresh weight and dry weight from the plants grown under $25^{\circ} \mathrm{C}$ to determine the biomass of the plants due to the different combinations of water and nitrogen availability. All data collected during the experiments are available in the Figshare repository (https://doi.org/10.6084/m9.figshare.13317686).

\section{Pollination efficacy treatment and field pollination observation}

To determine the impact of the treatments on the pollination efficacy of S. alba, hand pollinated self- and cross-pollination were carried out in the greenhouse on the plants grown in the winter (average $21^{\circ} \mathrm{C}$ ). Flower were marked and fruit and seed production were recorded after the completion of seed development. Plants grown in the spring (average $\left.25^{\circ} \mathrm{C}\right)$ and the summer $\left(29^{\circ} \mathrm{C}\right)$ were brought outside and placed in a sunny location nearby the Institute to assess the pollinator response and natural pollination efficacy rate. First pollinator observation was carried out in the spring for the plants grown under $25^{\circ} \mathrm{C}$ and second observation carried out in summer for the plants grown in $29^{\circ} \mathrm{C}$. Plants were observed for 30 minutes, from 9:00 to 14:00. We always exposed four plants at the same time (one plant from each of the four water $\mathrm{x}$ nitrogen combinations), placed $1 \mathrm{~m}$ apart in a square configuration. Altogether, forty-four observations were done for four types of plants from two temperature groups, which resulted into a total 22 hours of observation for 8 types of plants and each treatment received on average total 165 minutes of observation. Pollinators were observed, collected and identified in the field. Later, the plants were brought back to the greenhouse and flowers were marked to determine the seed production through the natural pollination by measuring the seed production rate after fruiting (data: https://doi.org/10.6084/m9.figshare.13317686). 


\section{Statistical analysis}

We used generalised linear models (GLM) to assess the individual and interactive impact of water, $\mathrm{N}_{2}$, and temperature on the plant's height, diameter, number of leaves, flowering time, flower and nectar production. The availability of water, nitrogen, and temperature were used as factors in the analyses. Depending on the character of the response variable, we specified the GLM with either Gaussian error distribution, overdispersed Poisson (“quasipossion”, the number of flowers), or Gamma distribution with a log link function (onset of flowering and nectar volume). We analysed data from the outdoor flower visitation experiment using GLM with water, nitrogen level, and year as factors, and using the overdispersed Poisson (“quasipossion”) error distribution. We analogously analysed also data on seed set of plants depending on growing conditions. We always examined the distribution of residuals to verify that the models fitted the data well. All analyses were done using the $\mathrm{R}$ programming environment Version 3.6.3 (R Core Team 2020) and graphs and plots were created using GraphPad Prism (Version 6.01, for Windows, GraphPad Software, San Diego, California USA, www.graphpad.com).

\section{Results}

\section{The effects of environmental factors on vegetative traits}

We observed a complex response of the selected vegetative traits of $S$. alba to the three environmental variables. The differences among the plants were visible from their morphological growth (Fig. 1). Plant height was affected by a three-way interaction of water availability, nitrogen, and temperature, i.e. the effect of each variable was dependent on the values of the other two variables (Table 1, Fig. 2a). While higher water availability made the plants taller (especially at higher temperatures), increasing nitrogen availability made the plants shorter. We also observed a negative effect of temperature - plants grown at the highest temperature were almost 50\% shorter than those grown at the lowest temperature (Fig. 2a). Stem diameter was affected by water and nitrogen, in both cases in interaction with temperature (Table 1). The plants had larger stem diameter under the conditions of higher water availability and lower temperature. Interestingly, higher nitrogen availability increased stem diameter at the highest and lower temperature but had a weak opposite effect at the intermediate temperature (Fig. 2b). Stem diameter increased in $21^{\circ} \mathrm{C}$ and $29^{\circ} \mathrm{C}$ temperatures and decreased in $25^{\circ} \mathrm{C}$ temperature with the addition of higher amount of $\mathrm{N}_{2}$. On the other hand, the number of leaves was affected only to a limited degree by an interaction of water and temperature - the plants had a higher number of leaves under higher water availability and intermediate temperature, while the effect was negligible under the lowest and highest temperatures (Fig. 2c). Finally, dry weight, which was measured only under the intermediate temperature, was more than $2.5 \mathrm{x}$ higher under high water availability, with a weak effect of nitrogen (Fig. 2d, fresh weight showed a very similar pattern). 

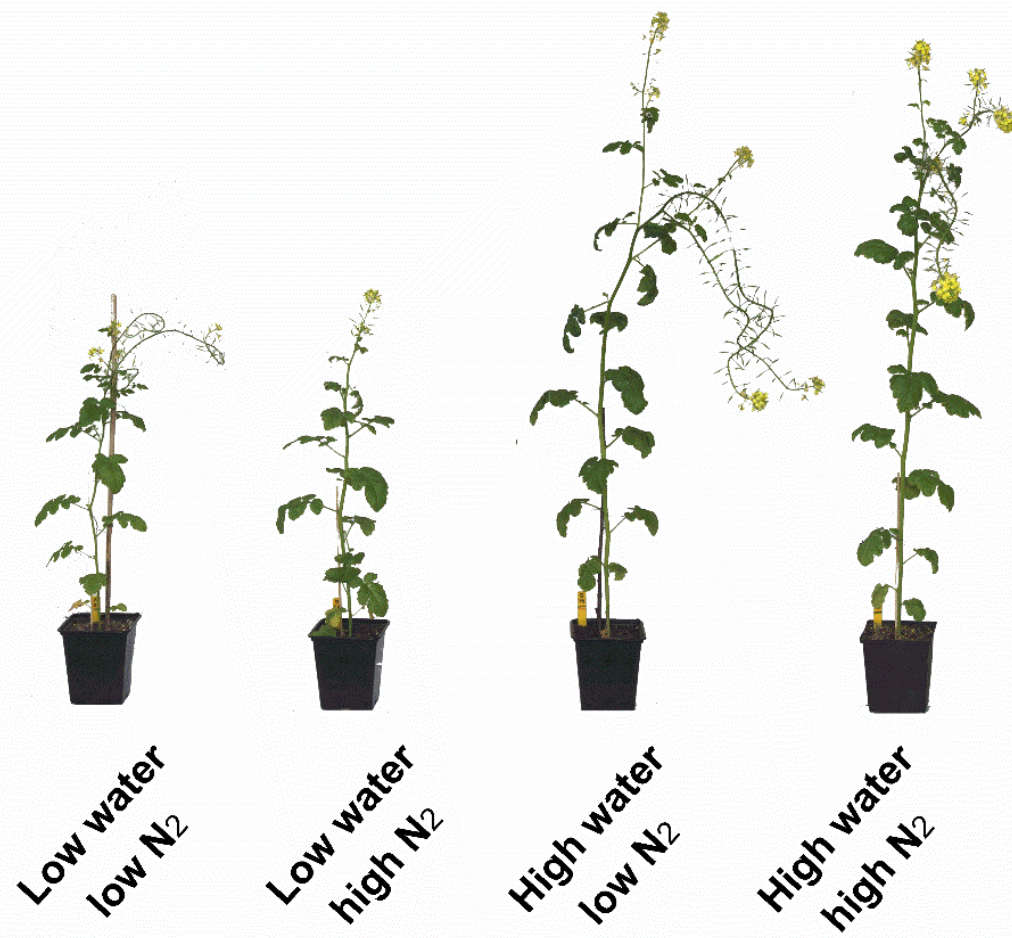

Treatments

Figure 1: The example of plant individuals grown under varying levels of water and nitrogen availability under the intermediate temperate $\left(25^{\circ} \mathrm{C}\right)$.

Table 1: Results of $\mathrm{F}$ and $\mathrm{P}$ values for individual variables and their interactions estimated by generalised linear models (see Methods) of the effects of water, nitrogen deposition, and temperature on several vegetative traits describing plant growth, where dry weight was measured only during spring 2017 at intermediate temperature, so the effect of temperature on dry weight was not tested.

\begin{tabular}{|l|c|c|c|c|c|c|c|c|}
\hline Variable & \multicolumn{2}{|c|}{ Plant height } & \multicolumn{2}{c|}{ Stem diameter } & \multicolumn{2}{c|}{ Leaf number } & \multicolumn{2}{c|}{ Dry weight } \\
\hline & $\mathbf{F}$ & $\mathbf{P}$ & $\mathbf{F}$ & $\mathbf{P}$ & $\mathbf{F}$ & $\mathbf{P}$ & $\mathbf{F}$ & $\mathbf{P}$ \\
\hline $\begin{array}{l}\text { water x nitrogen x tem- } \\
\text { perature }\end{array}$ & $\mathbf{5 . 0}$ & $\mathbf{0 . 0 0 8}$ & 1.2 & 0.306 & 0.1 & 0.951 & NA & NA \\
\hline water x nitrogen & 2.1 & 0.147 & 2.1 & 0.154 & 1.9 & 0.167 & $\mathbf{5 . 5}$ & $\mathbf{0 . 0 2 3}$ \\
\hline water x temperature & 2.2 & 0.113 & $\mathbf{3 . 1}$ & $\mathbf{0 . 0 4 7}$ & $\mathbf{3 . 3}$ & $\mathbf{0 . 0 3 9}$ & NA & NA \\
\hline nitrogen x temperature & 0.5 & 0.636 & $\mathbf{1 4 . 4}$ & $<\mathbf{0 . 0 0 1}$ & 0.2 & 0.817 & NA & NA \\
\hline water & $\mathbf{2 3 . 2}$ & $<\mathbf{0 . 0 0 1}$ & $\mathbf{3 2 . 9}$ & $<\mathbf{0 . 0 0 1}$ & 8.8 & 0.004 & $\mathbf{1 0 5 . 7}$ & $<\mathbf{0 . 0 0 1}$ \\
\hline nitrogen & $\mathbf{2 2 . 3}$ & $<\mathbf{0 . 0 0 1}$ & $\mathbf{2 4 . 1}$ & $<\mathbf{0 . 0 0 1}$ & 0.1 & 0.787 & 0.2 & 0.643 \\
\hline temperature & $\mathbf{6 0 . 7}$ & $<\mathbf{0 . 0 0 1}$ & $\mathbf{4 1 . 9}$ & $<\mathbf{0 . 0 0 1}$ & 9.0 & $<\mathbf{0 . 0 0 1}$ & NA & NA \\
\hline
\end{tabular}


a)

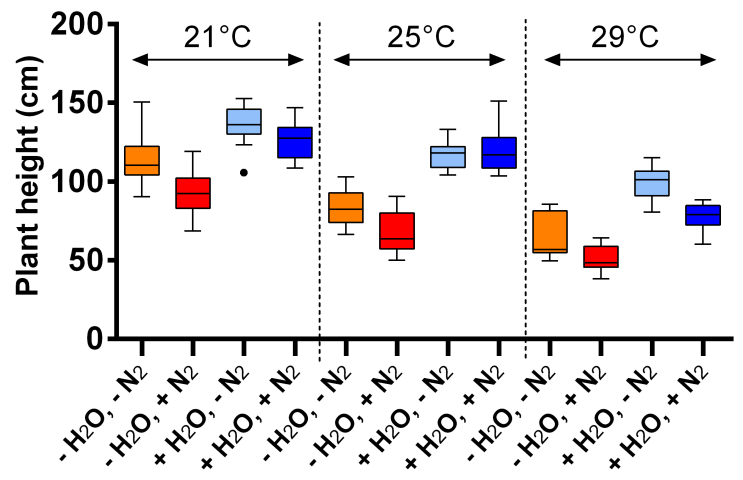

c)

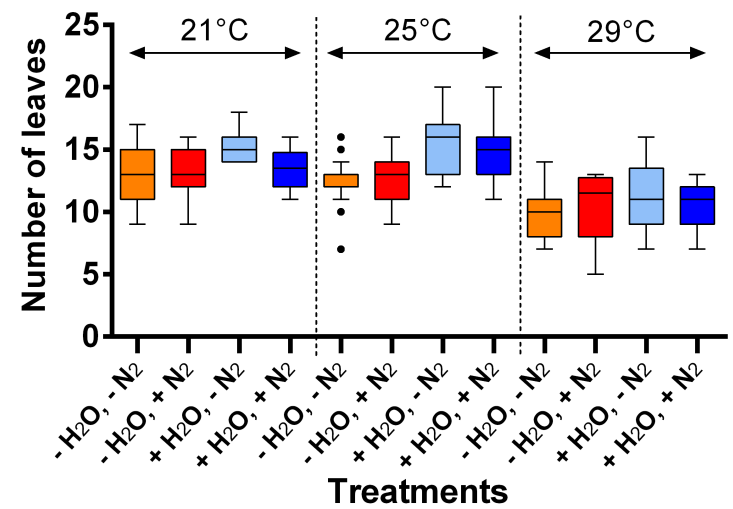

b)

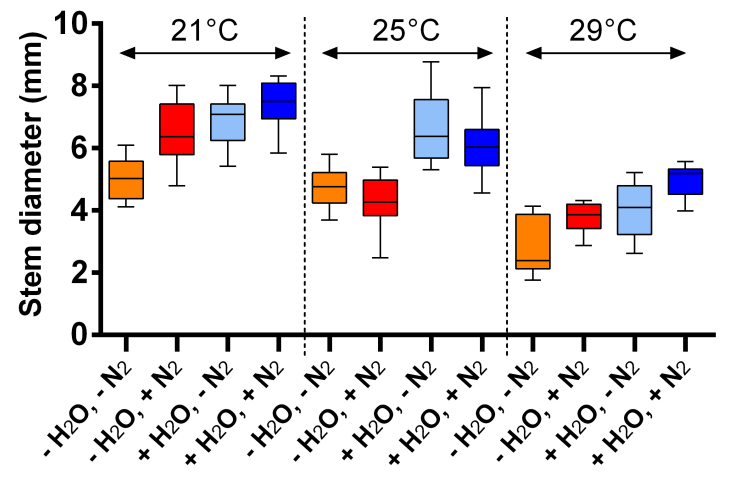

d)

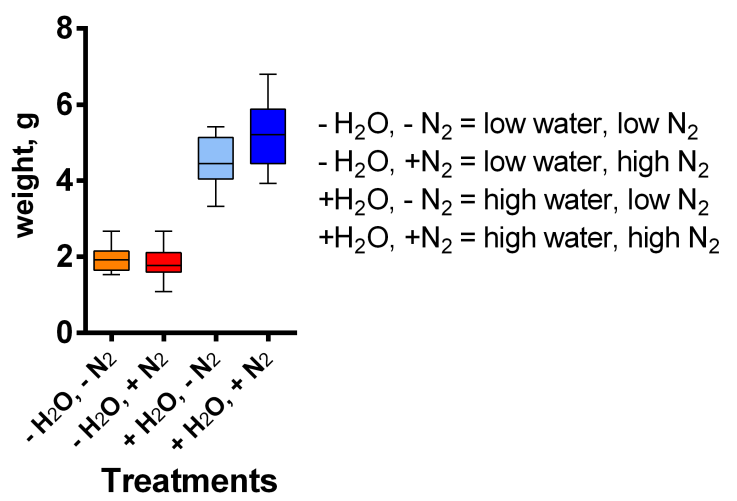

Figure 2: Impact of temperature, water and $\mathrm{N}_{2}$ supplementation on vegetative traits of S. alba; a) plant height; b) plant diameter; c) the number of leaves; d) dry weight. Results of statistical tests are summarised in Table 1.

\section{Phenology and flower resource variation}

All three environmental variables had a significant effect on some of the floral traits we measured. First, the number of flowers produced over the plants' flowering period was affected by an interaction of water and nitrogen availability and interaction of water and temperature (Table 2, Fig. 3). The plants generally produced a higher number of flowers under high water availability, although the strength of this effect varied with temperature, while there was a week trend of reduced number of flowers by high nitrogen availability when water availability was low, although the effect was not entirely convincing (Table 2, Fig. 3a). Second, the onset of flowering was delayed by low temperature and slightly also by high nitrogen availability (Fig. 3b). First flower emergence was delayed by ca. 21 days at the lowest temperature $\left(21^{\circ} \mathrm{C}\right)$ compared to $25^{\circ} \mathrm{C}$ and $29^{\circ} \mathrm{C}$. Finally, nectar volume showed a complex dependence on the interaction of all three environmental variables. Higher water availability increased nectar volume under low temperature, but not under intermediate and high temperature, while higher nitrogen availability increased nectar volume under low water availability and intermediate or high temperature (Fig. 3c). Nectar volume was also generally maximised under intermediate temperature. 
Table 2: The Results of $\mathrm{F}$ and $\mathrm{P}$ values for individual variables and their interactions estimated by generalised linear models (see Methods) of the effects of water, nitrogen deposition, and temperature on floral traits.

\begin{tabular}{|l|c|c|c|c|c|c|}
\hline Variable & \multicolumn{2}{|c|}{ Flower number } & \multicolumn{2}{c|}{ Onset of flowering } & \multicolumn{2}{c|}{ Nectar volume } \\
\hline & $\mathbf{F}$ & $\mathbf{P}$ & $\mathbf{F}$ & $\mathbf{P}$ & $\mathbf{F}$ & $\mathbf{P}$ \\
\hline water x nitrogen x temperature & 1.3 & 0.288 & 0.1 & 0.950 & $\mathbf{3 . 6}$ & $\mathbf{0 . 0 3 0}$ \\
\hline water x nitrogen & $\mathbf{6 . 1}$ & $\mathbf{0 . 0 1 5}$ & 0.0 & 0.930 & 0.2 & 0.648 \\
\hline water x temperature & $\mathbf{3 . 5}$ & $\mathbf{0 . 0 3 3}$ & 0.5 & 0.595 & 1.2 & 0.318 \\
\hline nitrogen x temperature & 1.3 & 0.265 & 0.6 & 0.564 & $\mathbf{8 . 8}$ & $<\mathbf{0 . 0 0 1}$ \\
\hline water & $\mathbf{1 1 . 6}$ & $<\mathbf{0 . 0 0 1}$ & 2.9 & 0.089 & $\mathbf{4 . 9}$ & $\mathbf{0 . 0 2 8}$ \\
\hline nitrogen & $\mathbf{8 . 4}$ & $\mathbf{0 . 0 0 4}$ & $\mathbf{1 1 . 3}$ & $\mathbf{0 . 0 0 1}$ & 0.2 & 0.622 \\
\hline temperature & $\mathbf{2 5 . 1}$ & $<\mathbf{0 . 0 0 1}$ & $\mathbf{1 7 7 . 9}$ & $<\mathbf{2 e}-\mathbf{1 6}$ & $\mathbf{1 0 . 7}$ & $<\mathbf{0 . 0 0 1}$ \\
\hline
\end{tabular}


a)

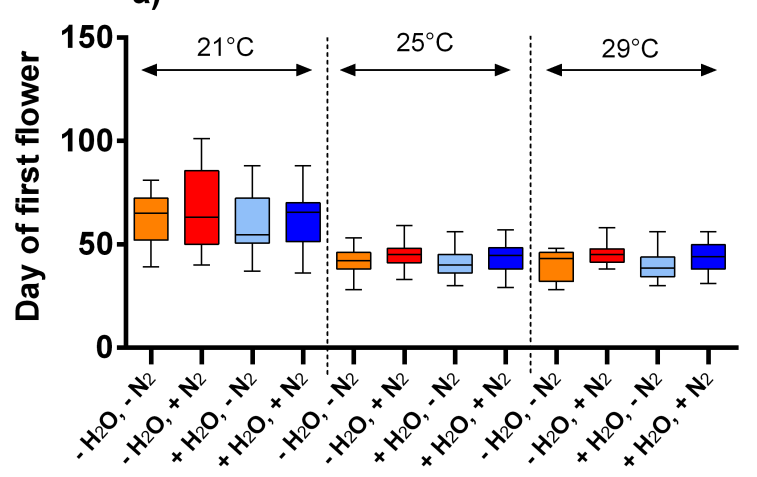

c)

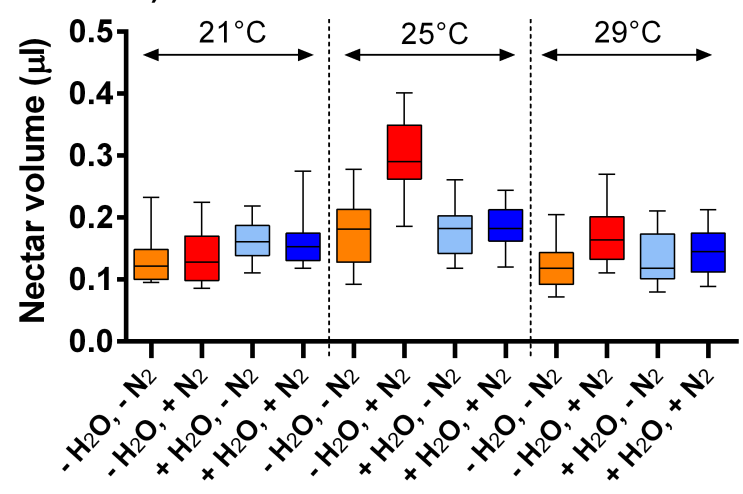

Treatments b)

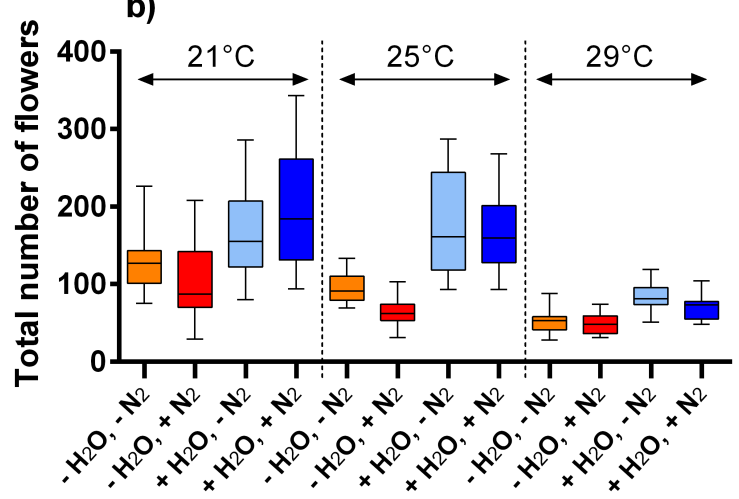

- $\mathrm{H}_{2} \mathrm{O},-\mathrm{N}_{2}=$ low water, low $\mathrm{N}_{2}$

$-\mathrm{H}_{2} \mathrm{O},+\mathrm{N}_{2}=$ low water, high $\mathrm{N}_{2}$

$+\mathrm{H}_{2} \mathrm{O},-\mathrm{N}_{2}=$ high water, low $\mathrm{N}_{2}$

$+\mathrm{H}_{2} \mathrm{O},+\mathrm{N}_{2}=$ high water, high $\mathrm{N}_{2}$

Figure 3: Impact of water, temperature and $\mathrm{N}_{2}$ on the flowering time, flower and nectar production of S. alba: a) the onset of flowering (the day of the opening of the first flower), b) the number of flowers produced per plant and c) nectar production.

\section{Response of pollinators}

We observed flower visitation by eight major types of flower-visiting insects in the spring of 2017 and summer 2018 which we distinguished as: the honeybee Apis mellifera, solitary bees, wasps, bumblebees, rapeseed beetles Brassicogethes (=Meligethes) sp., other beetles, hoverflies, and other flies. Rapeseed beetles were the most abundant flower visitors in the spring 2017, followed by honeybees, while solitary bees were dominant in the summer 2018, followed by hoverflies.

Plants grown with high amount of water were visited more frequently than the plants grown with low amount of water (GLM, F=23.6, P<0.001) in both spring 2017 and summer 2018, and the total number of flower visitors was higher in the spring 2017 (GLM, F=14.2, $\mathrm{P}<0.001$ ) (Fig. 4a, b). Nitrogen availability under which the plants were grown did not consistently affect their flower visitation (GLM, $\mathrm{F}=0.26, \mathrm{P}=0.612$ ). Flower visitation was also affected by the number of open flowers (GLM, $F=18.9, P<0.001$, Fig. 4c) and by the plant height (GLM, $F=8.9, P=0.003$, Fig. 4d), but the effect of water availability and year remained significant even after accounting for the variation in flower number and height (GLM, F=5.5, $\mathrm{P}=0.021$ for the effect of water and $\mathrm{F}=6.6, \mathrm{P}=0.011$ for the effect of the year), i.e. the differences in flower visitation between plants grown under different conditions were driven 
by a more complex set of differences between the plants. In addition to differences in total flower visitation, we detected changes in the composition of the flower visitors observed on plants grown under different water availability according to a redundancy analysis (RDA) performed separately for observations from the spring 2017 ( $\mathrm{F}=4.0, \mathrm{P}=0.004)$ and summer 2018 ( $\mathrm{F}=3.1, \mathrm{P}=0.028$ ), while nitrogen availability under which the plants were grown did not affect the composition of flower visitors ( $\mathrm{F}=0.37, \mathrm{P}=0.869$ for spring 2017 and $\mathrm{F}=0.57$, $\mathrm{P}=0.669$ for summer 2018). Some flower visitors visited plants grown under high water availability more frequently (e.g. solitary bees and rapeseed beetles), others apparently did not discriminate based on that - see Fig. 5.

a) Spring 2017

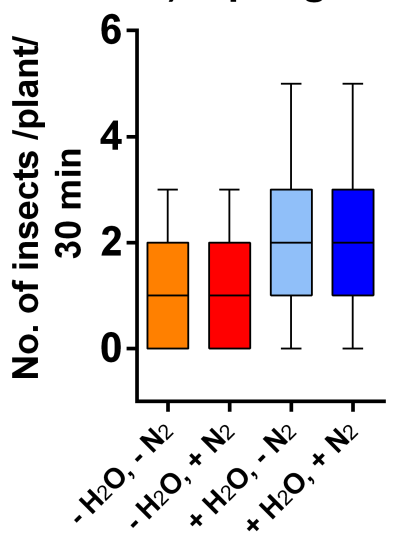

Treatments

c)

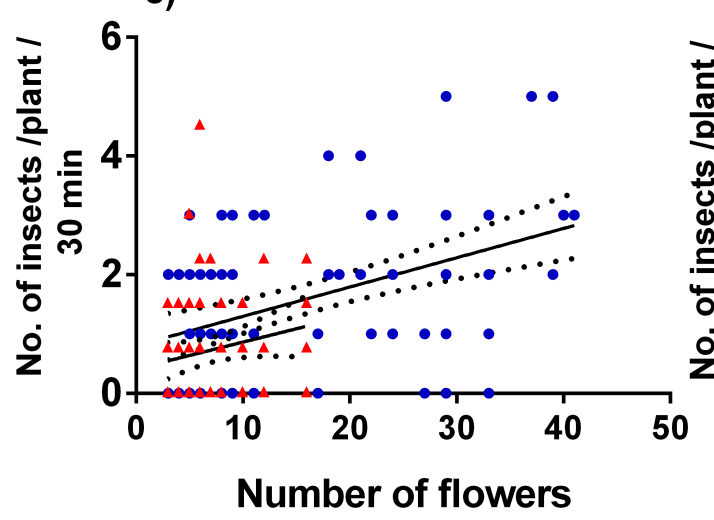

b) Summer 2018

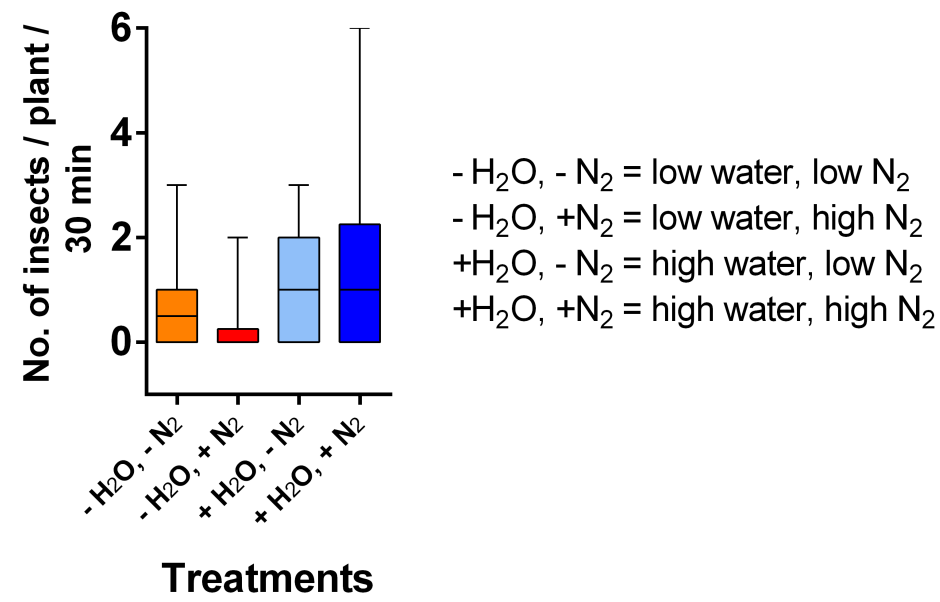

d)

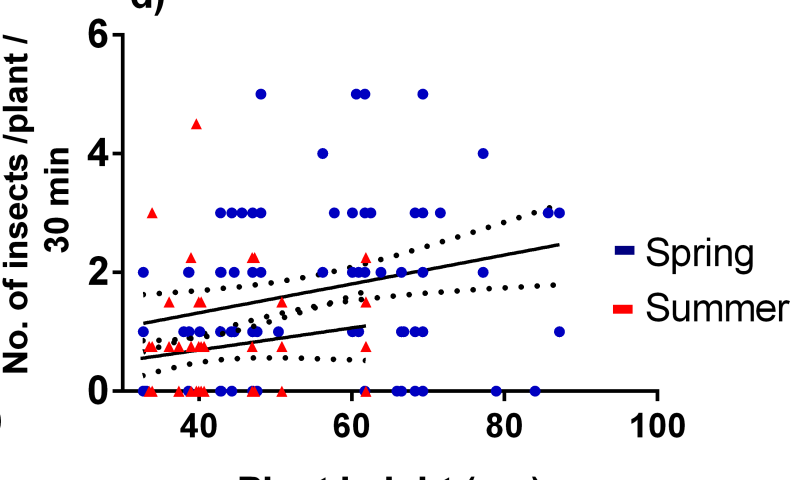

Plant height (cm)

Figure 4: Flower visitation of plants grown under varying water and nitrogen availability. The number of flower visitors per plant per 30 minutes during two observation periods are shown: a) spring 2017 (plants grown in the temperature of $25^{\circ} \mathrm{C}$ ) and b) summer 2018 (plants grown in $29^{\circ} \mathrm{C}$ ). Flower visitation also varied depending on the number of open flowers (c) and plant height (d). 


\section{a) Spring 2017}

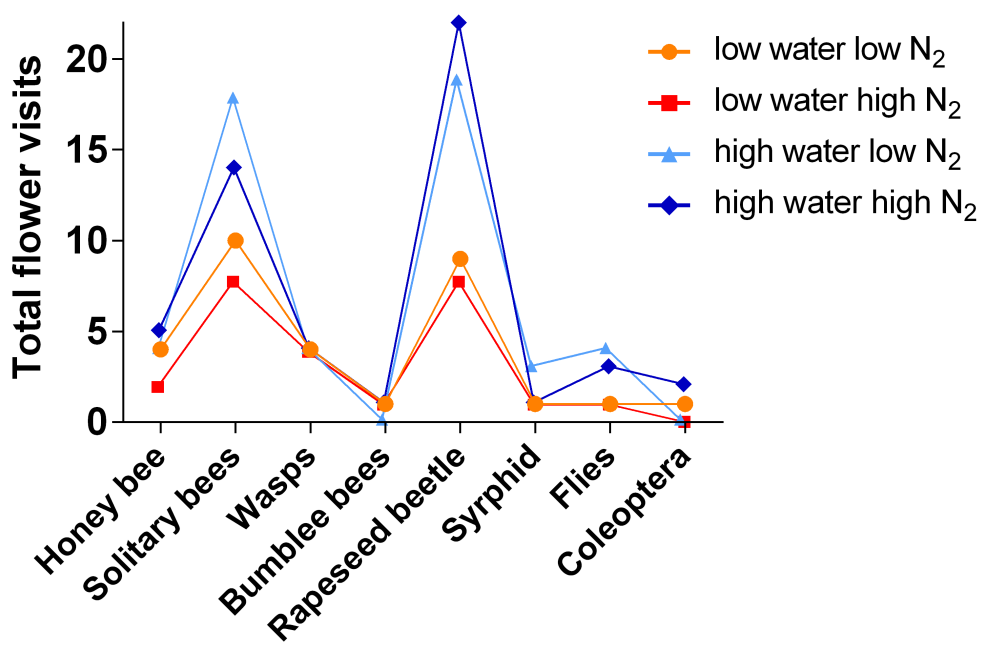

Flower visiting insect groups

b) Summer 2018

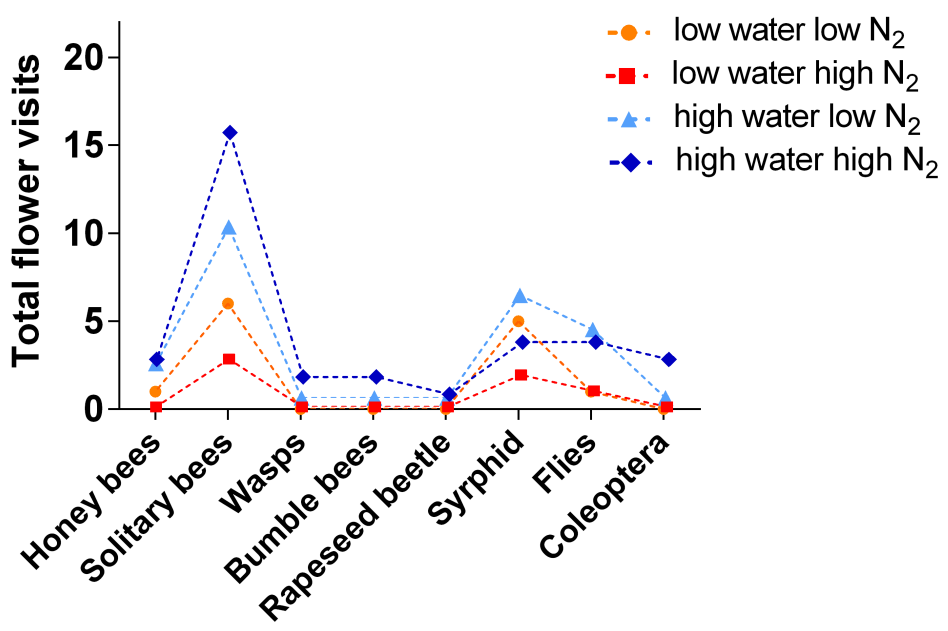

Flower visiting insect groups

Figure 5: Pollinator responses towards the plants grown under $25^{\circ} \mathrm{C}$ and $29^{\circ} \mathrm{C}$ in spring (a) and summer (b), respectively.

\section{Pollination efficacy and seed production}

S. alba shows partial self-incompatibility in pollination and our hand pollination results also confirmed it. Plants cross-pollinated by hand using a brush produced ca. 3.9 times higher number of seeds per flower than the self-pollinated ones; on average 2.9 compared to 0.7 seeds per flower (Fig. 6a). However, the seed set depended not just on the mode of pollination (self-pollinated compared to cross-pollinated) but on its interaction with nitrogen availability (GLM, F=10.6, $\mathrm{P}=0.002$ ). Specifically, higher nitrogen availability increased seed set in self-pollinated plants, but decreased seed set in cross-pollinated plants. In addition, 
higher water availability increased seed set in both self-pollination and cross-pollination irrespective of the nitrogen level (GLM, F=5.2, $\mathrm{P}=0.028$ ) (Fig. 6b).

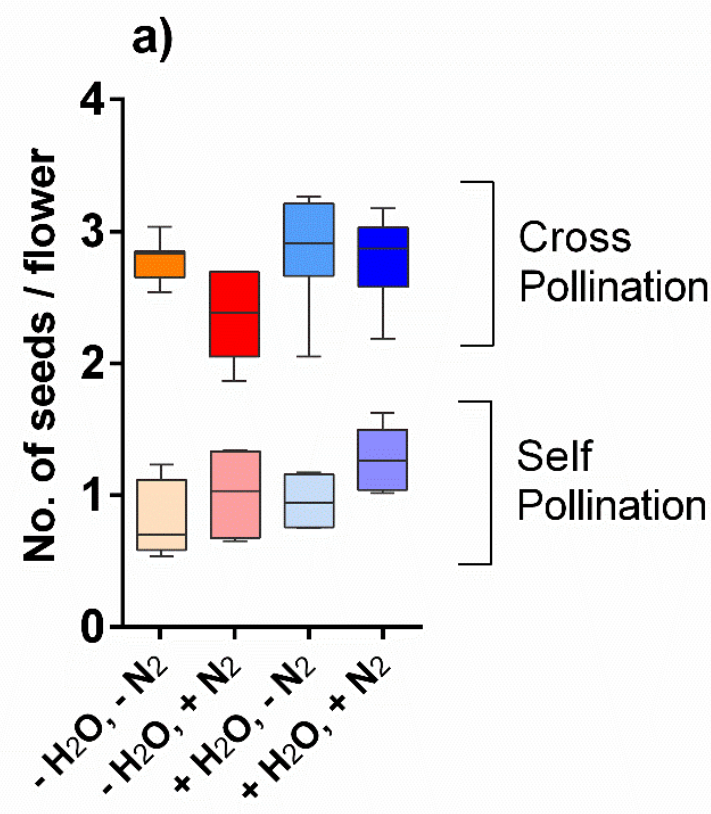

Treatments b)

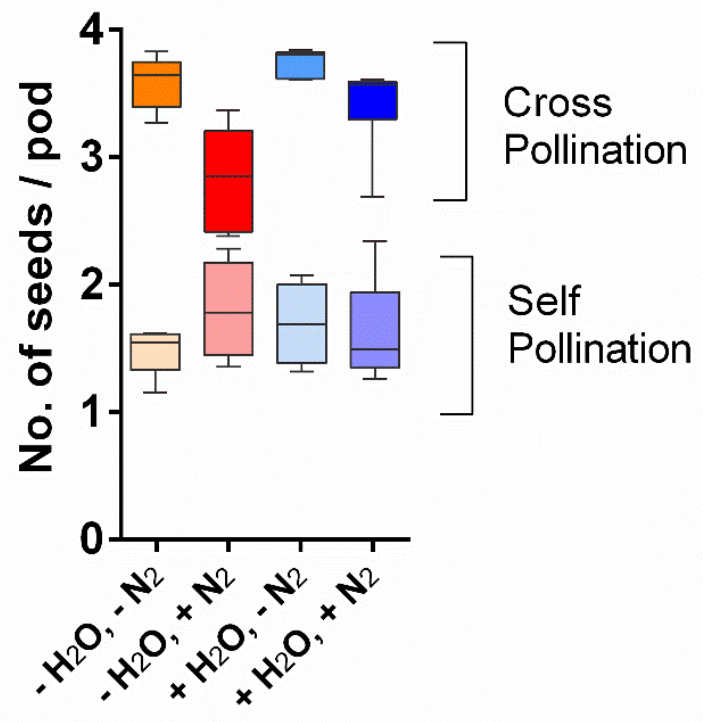

Treatments

Figure 6: Seed production after the hand pollination of $S$. alba grown under different growing conditions: a) seed production per flower and b) seed production per fruit. X-axis labels: $-\mathrm{H}_{2} \mathrm{O},-\mathrm{N}_{2}=$ low water and low $\mathrm{N}_{2} ;-\mathrm{H}_{2} \mathrm{O},+\mathrm{N}_{2}$ = low water and high $\mathrm{N}_{2} ;+\mathrm{H}_{2} \mathrm{O},-\mathrm{N}_{2}=$ high water and low $\mathrm{N}_{2} ;+\mathrm{H}_{2} \mathrm{O}$, $+\mathrm{N}_{2}=$ high water and high $\mathrm{N}_{2}$.

Plants exposed to natural pollination in two periods, spring 2017 and summer 2018, produced a variable number of seeds per flower depending on the interaction of water availability and year (GLM, F=9.0, P=0.004) and on the nitrogen availability (GLM, $F=5.1, P=0.028)$. We observed a slightly higher number of seeds per flower in plants grown under high water availability in the spring 2017, but lower in the summer 2018. In addition, plants grown under higher nitrogen availability produced a lower number of seeds per flower (Fig. 7a). As we showed above, plants grown under different combinations of water and nitrogen availability varied in their total production of flowers. Combined with the variation in the number of seeds produced per flower, this led to differences in the total seed set per plant (Fig. $7 \mathbf{b}$ ). Specifically, total seed set was higher in plants grown under high water availability, but the effect was stronger in the summer 2018 than in the spring 2017 (the interaction between water availability and year, GLM, F= 5.1, P=0.028). 
a)

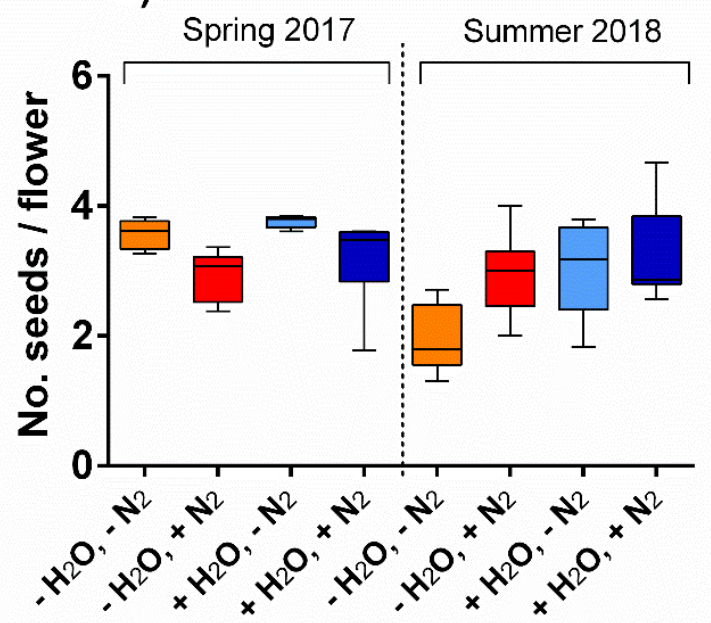

Treatments

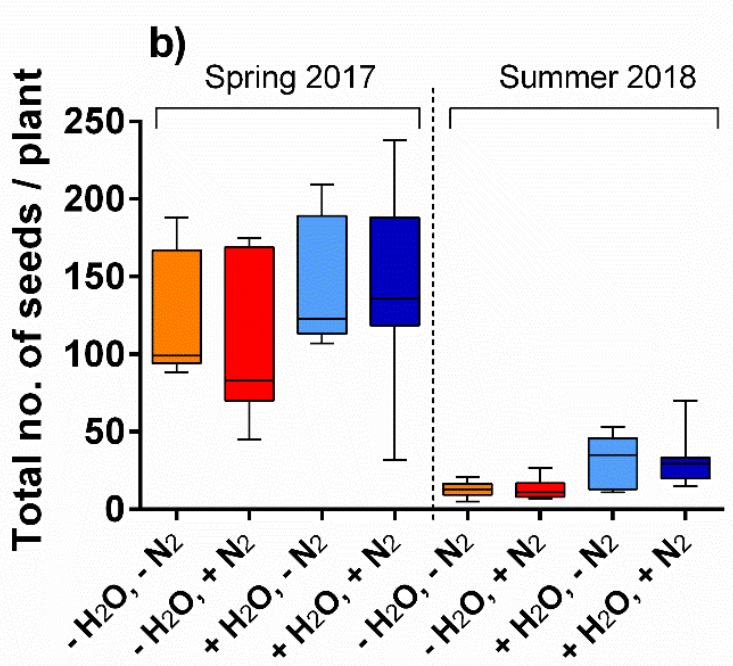

Treatments

Figure 7: Seed production of S. alba for treatment groups after natural pollination in two seasons. a) the number of seeds per flower in the spring 2017 and the summer 2018, and (b) the total seed set per plant in the spring 2017 and the summer 2018 in plants exposed to natural pollination. X-axis labels: $\mathrm{H}_{2} \mathrm{O},-\mathrm{N}_{2}=$ low water and low $\mathrm{N}_{2} ;-\mathrm{H}_{2} \mathrm{O},+\mathrm{N}_{2}=$ low water and high $\mathrm{N}_{2} ;+\mathrm{H}_{2} \mathrm{O},-\mathrm{N}_{2}=$ high water and low $\mathrm{N}_{2} ;+\mathrm{H}_{2} \mathrm{O},+\mathrm{N}_{2}=$ high water and high $\mathrm{N}_{2}$.

\section{Discussion}

\section{Response of plant growth and floral traits to the changing environmental factors}

Generally, plant's growth and fitness increase with the increasing temperature, reach a transition peak at an optimal temperature and rapidly decrease beyond this optimal range (Vasseur et al., 2014, Hatfield \& Prueger, 2015) and a similar trend was also found in our experiment, where $S$. alba grew better in $21^{\circ} \mathrm{C}$ and $25^{\circ} \mathrm{C}$ temperatures compared to a higher temperature $\left(29^{\circ} \mathrm{C}\right)$. Overall height, stem diameter and number of leaves dropped with increasing temperature, but this was also highly dependent on water availability, where higher amount of water positively affected plant growth, especially in higher temperatures. In nature, these responses can vary species to species and depend on the precipitations and aridity index of a region (Zeppel et al., 2014; Chen et al., 2018). $\mathrm{N}_{2}$ supplementation had more complex role in the morphological growth of $S$. alba and its effect was modulated by temperature and water availability. Water deficiency leads to reduced biomass production and diminished $\mathrm{N}_{2}$ uptake in plants (Cossani et al., 2012), but, sufficient nitrogen supply may enhance drought tolerance and increase water use efficiency in plants (Quemada \& Gabriel, 2016). In all our temperature conditions, additional $\mathrm{N}_{2}$ supplementation to $S$. alba decreased the plant height regardless of the amount of water supplementation. However, the impact of $\mathrm{N}_{2}$ on stem diameter largely depend on the water availability and temperature. In addition, results of measurements of fresh and dry weight of the plants grown in $25^{\circ} \mathrm{C}$ temperature also showed that higher availability of $\mathrm{N}_{2}$ had positive impact on plant biomass when higher amount of water was given, but not when low amount of water was available. 
Flowering phenology, number of flowers and nectar production of S. alba were also highly affected by these climatic drivers. First flower emergence was significantly delayed at the lowest temperature $\left(21^{\circ} \mathrm{C}\right)$ compared to $25^{\circ} \mathrm{C}$ and $29^{\circ} \mathrm{C}$ and the onset of flowering was also delayed by high nitrogen availability across all temperature and water levels. Similar observational studies also showed this trend where plant phenological shifts are closely related to temperature (Jagadish et al., 2016; Kehrberger \& Holzschuh, 2019). Another study showed that increasing temperature caused flower bud abortion and significantly reduced the total number of flowers produced by Borago officinalis (Descamps et al., 2018). Similarly, the total number of flowers of $S$. alba significantly dropped in our experiment with increasing temperature. However, the fact that plants produced more flowers with high amount of water, even at the highest temperature, shows that thermal stress can be reduced in plants by water supplementation (see also Mahan et al., 1995; Li et al., 2020).

An optimal temperature is also required for the maximum nectar secretion, and nectar production can be decreased in lower or higher temperatures (Pacini \& Nepi, 2007, Lu et al., 2015). In our case, S. alba produced comparatively higher amount of nectar at the intermediate temperature $\left(25^{\circ} \mathrm{C}\right)$. However, nectar production was affected by a complex interaction of all three variables with high water availability, where nectar production increased at low temperature, but not at intermediate and high temperature. Moreover, higher levels of nitrogen increased nectar production at intermediate and high temperatures, but only under low water availability. This is mechanistically a complex relationship, not reported by previous studies on other plant species. Contrary to our results, several studies showed that nectar production may decline with water reduction and increased temperature (Keasar et al., 2008; Scaven \& Rafferty, 2013; Takkis et al., 2015). In our case, nectar production did not decrease under these conditions and also showed an opposite result compared to Hoover et al., (2012), where nectar production of Cucurbita maxima was positively affected by increasing temperatures and low $\mathrm{N}_{2}$ supplementation. However, our results are supported by the findings of Villarreal \& Freeman (1990), who showed that nectar production of Ipomopsis longiflora was affected by water supplementation and not by the temperature. This concludes that different plant species have different strategies to cope with environmental stress that can lead to contrasting species-specific effects of variation of weather conditions on nectar production (Lu et al., 2015). Apart from temperature, the plants could have been affected also by differences in day length and light intensity, although we tried to limit their impact by using artificial lights in the greenhouse, so we don't expect this to affect our results. In addition, a positive aspect of our experimental setting was that the plants were exposed to natural day-night variation of temperature, rather than being grown under constant temperature.

\section{Impact on pollination and seed production}

Pollinator's attraction to a plant depends on visual cues indicating high floral reward such as the number of open flowers (Akter et al., 2017) and the size of floral display (Biella et al., 2019), and on the amount and quality of nectar and pollen (Cresswell, 1999; Grindeland et al., 2005), along with general conspicuousness of the plant which increases its detection by 
potential pollinators, such as plant height (Junker et al., 2013; Klecka et al., 2018a; Hernández-Villa et al., 2020), local plant clustering (Elliot \& Irwin, 2009; Akter et al., 2017), and flower colour (Reverté et al., 2016). Our experiments showed that, these morphological trait differences among the plants had a cascading effect on the number and identity of flower visitors of $S$. alba and on its reproduction. Measurements of flower visitation with plants grown at $25^{\circ} \mathrm{C}$ in the spring 2017 and plants grown at $29^{\circ} \mathrm{C}$ in the summer 2018 revealed that and in both cases plants grown with higher amount of water had a significantly higher number of flower visitors compared to plants grown under low amount of water irrespective of the nitrogen availability. This is likely a consequence of differences in vegetative and floral traits induced by differences in water availability. As discussed above, plants grown with high amount of water were taller and produced more flowers and these characteristics had a positive effect on the visitation of individual plants as reported in other plant species (e.g. Mitchell et al. 2004; Akter et al., 2017; Klecka et al., 2018a). However, other modifications of plant traits induced by water stress also decreased the visitation of plants grown with low amount of water, because the effect of water availability on the number of flower visitors per plant was significant even after accounting for differences in the number of open flowers and plant height. The remaining unexplained variation could be related to nectar chemistry (Petanidou et al., 2006; Hoover et al., 2012) or flower scent (FarréArmengol et al., 2020).

Besides having lower flower visitation, plants grown under low amount of water had different composition of flower visitors compared to plants grown with higher amount of water. In the spring 2017, plants grown with high amount of water received more frequent visits from rapeseed beetles, solitary bees and hoverflies than plants grown under low amount of water, while the other flower visitors, including honeybees and bumblebees, did not discriminate among the plants. The results were similar in the summer 2018, although rapeseed beetles were almost absent. The observed differences in the flower visitation in the summer 2018 and spring 2017 may be influenced by the differences in overall insect abundance or weather, but not necessarily by the growing conditions of the plants. For instance, increasing temperature may affect flower visitation by a number of mechanisms, from differences in plant traits caused by high temperature stress (Descamps et al., 2018), through phenological shifts of plant flowering and pollinator emergence (Hegland et al., 2009; Bartomeus et al., 2011), to changes in pollinator foraging activity caused by their responses to temperature (Corbet et al., 1993) and direct and indirect effects of temperature on the fitness and mortality of pollinating insects.

Finally, seed production of $S$. alba was also affected by water and nitrogen availability, apparently both directly through physiological mechanisms and indirectly through changes in insect pollination. Our hand pollination assessment confirmed that $S$. alba is a partially selfincompatible plant (Fan et al., 2007) and low water availability reduced seed production per flower in both self-pollinated and cross-pollinated plants, which is consistent with previous studies suggesting that water stress may lead to seed or pod abortion (e.g. New et al., 1994; Behboudian et al., 2001). However, we also observed an intriguing effect of nitrogen availability on seed set: increased nitrogen availability increased seed set in self-pollinated plants, but decreased seed set in cross-pollinated plants. We are not aware of any studies 
which would show that high $\mathrm{N}_{2}$ can cause seed abortion, particularly under low water availability.

Seed count per flower from the naturally pollinated plants in the spring 2017 (grown under $25^{\circ} \mathrm{C}$ ) also showed a similar trend as in plants cross-pollinated by hand pollination, where the number of seeds per flower increased in plants grown with high water availability, but decreased with high nitrogen availability. In contrast, in experiments done in the summer 2018 (plants grown under $29^{\circ} \mathrm{C}$ ), the number of seeds per flower was not affected by nitrogen availability and decreased in plants grown with high amount of water. Total seed set per plant, depending on the flowers produced by plants grown in different combinations of water and nitrogen availability, was unaffected by nitrogen availability and increased in plants grown under high water availability - moderately in the spring 2017 but much more in the summer 2018. While data on flower visitation discussed above clearly showed higher visitation of plants grown under high water availability and no effect of nitrogen availability, the composition of the flower visitor community varied between plants grown under low and high water availability and the total visitation rate was generally higher in the spring 2017 than summer 2018. The level of pollen limitation was thus generally higher in the summer 2018, which could explain why the number of seeds per flower was lower and was more strongly reduced in plants which were grown with low amount of water. Our results on seed production in plants cross-pollinated by hand are consistent with this possibility, but the effect was not strong enough to explain variation in seed set in plants exposed to natural pollination by flower-visiting insects.

\section{Conclusions}

We conclude that multiple drivers of environmental change have a complex and interactive impact on plant traits, visitation by pollinators, and seed production. Our model species, $S$. $a l b a$, is an important crop itself and a close relative to many other economically important crops and vegetables from the Brassicaceae family, hence our experiment shows how different climatic drivers may affect both vegetative growth and crop yield in many plant species form this family in the future extreme climatic events.

\section{Acknowledgements}

We are grateful to Pavla Koloušková for her valuable help during the field observations and Jana Jersáková for her help with the laboratory analyses. This study was supported by the Czech Science Foundation (Grant no. GJ17-24795Y).

\section{Author contributions}

AA and JK planned and designed the research; AA collected the data; AA and JK analysed the data; and AA and JK wrote the manuscript. 


\section{Data Availability}

All data collected during the experiments are available in the Figshare repository (https://doi.org/10.6084/m9.figshare.13317686).

\section{References}

Akter A, Biella P, Klecka J. 2017. Effects of small-scale clustering of flowers on pollinator foraging behaviour and flower visitation rate. PLoS ONE 12(11): e0187976.

Albrigo LG, Russ R, Rouseff R, Bazemore RA. 2012. Some citrus flower characteristics and honeybee preference. Proc. Fla. State Hortic. Soc. 125: 112-118.

Aronson J, Kigel J, Shmida A. 1992. Adaptive phenology of desert and Mediterranean populations of annual plants grown with and without water stress. Oecologia 89:17-26.

Bahuguna RN, Krishna N, Jagadish SV. 2015. Temperature regulation of plant phenological development. Environmental and Experimental Botany 111: 83-90.

Baker HG, Baker I. 1983a. Floral nectar sugar constituents in relation to pollinator type. In: Jones C. E., Little R. J. (eds.) Handbook of experimental pollination biology. Van Nostrand Reinhold, New York, 117-141.

Barlow K, Christy B, O’Leary G, Riffkin P, Nuttall J. 2013. Simulating the impact of extreme heat and frost events on wheat production: the first steps in J. J. Piantadosi, R.J.B. Anderssen (Eds.), 20th International Congress on Modelling and Simulation, Modelling and Simulation Society of Australia and New Zealand, Adelaide, 545-551.

Barnabás B, Jäger K, Fehér A. 2008. The effect of drought and heat stress on reproductive processes in cereals. Plant Cell and Environment 31(1):11-38.

Bartomeus I, Ascher JS, Wagner D, Danforth BN, Colla S, Kornbluth S, Winfree R. 2011. Climate-associated phenological advances in bee pollinators and bee-pollinated plants. Proceedings of the National Academy of Sciences 108 (51): 20645-20649.

Bartomeus I, Park MG, Gibbs J, Danforth BN, Lakso AN, Winfree R. 2013. Biodiversity ensures plant-pollinator phenological synchrony against climate change. Ecology letters 16(11): 1331-1338.

Basnett S, Ganesan R, Devy SM. 2019. Floral traits determine pollinator visitation in Rhododendron species across an elevation gradient in the Sikkim Himalaya. Alp Botany 129: 81-94.

Behboudian MH, Ma Q, Turner NC, Palta JA. 2001. Reactions of chickpea to water stress: yield and seed composition. Journal of the Science of Food and Agriculture 81(13): 1288-1291.

Berdanier AB, Klein JA. 2011. Growing season length and soil moisture interactively constrain high elevation aboveground net primary production. Ecosystems 14: 963-974.

Bernal M, Estiarte M, Peñuelas J. 2011. Drought advances spring growth phenology of the Mediterranean shrub Erica multiflora. Plant Biology 13: 252-257. 
Biella P, Akter A, Ollerton J, Tarrant S, Janeček Š, Jersáková J, Klecka J. 2019. Experimental loss of generalist plants reveals alterations in plant-pollinator interactions and a constrained flexibility of foraging. Sci Rep 9: 7376.

Blum A. 1996. Crop responses to drought and the interpretation of adaptation. Plant Growth Regul 20: 135-148.

Bobbink R, Hornung M, Roelofs GM. 1998. The effects of air-borne nitrogen pollutants on species diversity in natural and semi-natural European vegetation. Journal of Ecology 86: 738.

Bobbink R, Hicks K, Galloway J, Spranger T, Alkemade R, Ashmore M, Bustamante M, Cinderby S, Davidson E, Dentener F et al. 2010. Global assessment of nitrogen deposition effects on terrestrial plant diversity: a synthesis. Ecological Applications 20(1): 30-59.

Burkle L, Irwin RE. 2009. The importance of interannual variation and bottom-up nitrogen enrichment for plant-pollinator networks. Oikos 118: 1816-1829.

Burkle LA, Irwin RE. 2010. Beyond biomass: measuring the effects of community level nitrogen enrichment on floral traits, pollinator visitation and plant reproduction. Journal of Ecology 98: 705- 717.

Carroll AB, Pallardy SG, Galen C. 2001. Drought stress, plant water status, and floral trait expression in fireweed, Epilobium angustifolium (Onagraceae). American Journal of Botany 88: 438- 446.

Carromero W, Hamrick JL. 2005. The mating system of Verbascum thapsus (Scrophulariaceae): the effect of plant height. International Journal of Plant Sciences 166: 979-983.

Chen J, Dong C, Yao X, Wang W. 2018. Effects of nitrogen addition on plant biomass and tissue elemental content in different degradation stages of temperate steppe in northern China. Journal of Plant Ecology 11(5): 730-739.

Christensen JH, Carter TR, Rummukainen M, Amanatidis G. 2007. Evaluating the performance and utility of regional climate models: the PRUDENCE project. Climatic Change 81: 1-6.

Corbet SA, Fussell M, Ake R, Fraser A, Gunson C, Savage A, Smith K. 1993. Temperature and the pollinating activity of social bees. Ecological Entomology 18: 17-30.

Cossani CM, Slafer GA, Savin R. 2012. Nitrogen and water use efficiencies of wheat and barley under a Mediterranean environment in Catalonia Field Crops Research 128: 109-118.

Cresswell JE. 1999. The influence of nectar and pollen availability on pollen transfer by individual flowers of oil seed rape (Brassica napus) when pollinated by bumblebees (Bombus lapidarius). Journal of Ecology 87(4): 670-677.

Descamps C, Quinet M, Baijot A, Jacquemart AL. 2018. Temperature and water stress affect plant-pollinator interactions in Borago officinalis (Boraginaceae) Ecol Evol. 8: 34433456. 
Ekanayake A, Strife RJ, Zehentbauer GN, David JRD. 2016. Yellow or White Mustard (Sinapis alba L.) Oils. In: Preedy, V.R. (editor) Essential Oils in Food Preservation, Flavor and Safety, Academic Press, UK, 857-863.

Elliott, SE, Irwin RE. 2009. Effects of flowering plant density on pollinator visitation, pollen receipt, and seed production in Delphinium barbeyi (Ranunculaceae). American Journal of Botany 96: 912-919.

Farré-Armengol G, Fernández-Martínez M, Filella I, Junker RR, Peñuelas J. 2020. Deciphering the biotic and climatic factors that influence floral scents: A systematic review of floral volatile emissions. Frontiers in Plant Science 11: 1154.

Fitter AH, Fitter RSR. 2002. Rapid changes in flowering time in British plants. Science 296: 1689-1691.

Flacher F, Raynaud X, Hansart A, Geslin B, Motard B, Verstraet S, Bataille M, Dajoz I. 2020. Below-ground competition alters attractiveness of an insect-pollinated plant to pollinators. AoB PLANTS 12(4): plaa022.

Forrest JR. 2015. Plant-pollinator interactions and phenological change: what can we learn about climate impacts from experiments and observations? Oikos 124(1): 4-13.

Gallagher MK, Campbell DR. 2017. Shifts in water availability mediate plant-pollinator interactions. New Phytol 215: 792-802.

Galen C. 1999. Why do flowers vary? The functional ecology of variation in flower size and form within natural plant populations. BioScience 49: 631-640.

Galen C. 2000. High and dry: drought stress, sex allocation trade offs, and selection on flower size in the alpine wildflower Polemonium viscosum (Polemoniaceae). American Naturalist 156: 72- 83.

Gardener MC, Gillman MP. 2001. The effects of soil fertilizer on amino acids in the floral nectar of corncockle, Agrostemma githago (Caryophyllaceae). Oikos 92:101-106.

Gardener MC, Gillman MP. 2002. The taste of nectar-a neglected area of pollination ecology. Oikos 98: 552-557.

Gérard M, Vanderplanck M, Wood T, Michez D. 2020. Global warming and plantpollinator mismatches. Emerg Top Life Sci 4 (1): 77-86.

Gray SB, Brady SM. 2016. Plant developmental responses to climate change. Arid Soil Research and Rehabilitation 2: 49-58.

Grindeland JM, Sletvold N, IMS, RA. 2005. Effects of floral display size and plant density on pollinator visitation rate in a natural population of Digitalis purpurea. Functional Ecology 19: 383-390.

Güsewell S, Furrer R, Gehrig R, Pietragalla B. 2017. Changes in temperature sensitivity of spring phenology with recent climate warming in Switzerland are related to shifts of the preseason. Glob Change Biol. 23: 5189- 5202. 
Hampton JG, Conner AJ, Boelt B, Chastain TG, Rolston, P. 2016. Climate Change: Seed Production and Options for Adaptation. Agriculture 6: 33.

Hatfield JL, Prueger JH. 2015. Temperature extremes: Effect on plant growth and development. Weather and Climate Extremes 10 (A): 4-10.

Hedhly A. 2011. Sensitivity of flowering plant gametophytes to temperature fluctuations. Environmental and Experimental Botany 74: 9- 16.

Hegland SJ, Totland Ø. 2005. Relationships between species' floral traits and pollinator visitation in a temperate grassland. Oecologia 145: 586-594.

Hegland SJ, Nielsen A, Lázaro A, Bjerknes AL, Totland $\varnothing$. 2009. How does climate warming affect plant pollinator interactions? Ecology Letters 12(2): 184- 195.

Hernández-Villa V, Vibrans H, Uscanga-Mortera E, Aguirre-Jaimes A. 2020. Floral visitors and pollinator dependence are related to floral display size and plant height in native weeds of central Mexico. Flora 262: 151505.

Hill CJ, Pierce NE. 1989. The effect of adult diet on the biology of butterflies 1. The Common Imperial Blue, Jalmenus evagoras. Oecologia 81:249-257.

Hodges S. 1995. The influence of nectar production on hawkmoth behavior, self pollination, and seed production in Mirabilis multifiora (Nyctagi- naceae). American Journal of Botany 82: 197-204.

Hoover SER, Ladley JJ, Shchepetkina AA, Tisch M, Gieseg SP, Tylianakis JM. 2012. Warming, $\mathrm{CO}_{2}$, and nitrogen deposition interactively affect a plant pollinator mutualism. Ecology Letters 15: 227-234.

Holtsford TP, Ellstrand NC. 1992. Genetic and environmental variation in floral traits affecting outcrossing rate in Clarkia tembloriensis (Onagraceae). Evolution 46: 216-225.

Fan HL, Sun WC, Yan N, Zhu HX, Wu JY, Zhang YH, Zeng J, Ye J, Liu YL. 2007. Analysis of self-compatibility in Sinapis alba (L.) Boiss. In Proceedings of the 12th International Rapeseed Congress, Wuhan, China, 26-30 March 2007, 368-369.

Inouye DW, Waller GD. 1984. Responses of honeybees (Apis mellifera) to amino acid solutions mimicking nectars. Ecology 65: 618- 625.

Inouye DW, Morales MA, Dodge GJ. 2002. Variation in timing and abundance of flowering by Delphinium barbeyi Huth (Ranunculaceae): The roles of snowpack, frost, and La Niña, in the context of climate change. Oecologia 130: 543-550.

IPCC. 2007. Climate Change 2007: Synthesis Report. Contribution of Working Groups I, II and III to the Fourth Assessment Report of the Intergovernmental Panel on Climate Change [Core Writing Team, Pachauri, R.K and Reisinger, A. (eds.)]. IPCC, Geneva, Switzerland, 104 pp.

Jabłoński B, Król S, Pliszka K, Żurowska Z. 1984. Nectar secretion and pollination of the blueberry (Vaccinium corymbosum L.). Acta Hortic. 165: 133-144. 
Jagadish SK, Bahuguna RN, Djanaguiraman M, Gamuyao R, Prasad PV, Craufurd PQ. 2016. Implications of high temperature and elevated $\mathrm{CO}_{2}$ on flowering time in plants. Front. Plant Sci. 7: 913.

Jauzein P. 2011. Flore des champs cultivés. 2nd edn. Versailles, France: Editions Quae.

Junker RR, Blüthgen N, Brehm T, Binkenstein J, Paulus J, Schaefer MH, Stang M. 2013. Specialization on traits as basis for the niche breadth of flower visitors and as structuring mechanism of ecological networks. Functional Ecology 27(2): 329-341.

Keasar T, Sadeh A, Shmida A. 2008. Variability in nectar production and standing crop, and their relation to pollinator visits in a Mediterranean shrub. Arthropod-Plant Interactions 2: 117-123.

Kehrberger S, Holzschuh A. 2019. Warmer temperatures advance flowering in a spring plant more strongly than emergence of two solitary spring bee species. PLoS ONE 14(6): e0218824.

Klecka J, Hadrava J, Koloušková P. 2018a. Vertical stratification of plant-pollinator interactions in a temperate grassland. PeerJ 6: e4998.

Klecka J, Hadrava J, Biella P, Akter A. 2018b. Flower visitation by hoverflies (Diptera: Syrphidae) in a temperate plant-pollinator network. PeerJ 6: e6025.

Kudo G. 1993. Relationship between flowering time and fruit set of the entomophilous alpine shrub, Rhododendron aureum (Ericaceae), inhabiting snow patches. American Journal of Botany 80: 1300-1304.

Lasky JR, Uriarte M, Muscarella R. 2016. Synchrony, compensatory dynamics, and the functional trait basis of phenological diversity in a tropical dry forest tree community: effects of rainfall seasonality. Environ. Res. Lett. 11: 115003.

Lee SG, Felker P. 1992. Influence of water/heat stress on flowering and fruiting of mesquite (Prosopis glandulosa var. glandulosa). Journal of Arid Environments 23: 309- 319.

Li Y, Guan K, Peng B, Franz TE, Wardlow B, Pan M. 2020. Quantifying irrigation cooling benefits to maize yield in the US Midwest. Glob Change Biol. 26: 3065-3078.

Lu NN, Li XH, Li L, Zhao ZG. 2015. Variation of nectar production in relation to plant characteristics in protandrous Aconitum gymnandrum. Journal of Plant Ecology 8(2): 122129.

Lunau K, Maier EJ. 1995. Innate colour preferences of flower visitors. Journal of Comparative Physiology A 177(1): 1-19.

Mahan JR, McMicheal BL, Wanjura DF. 1995. Methods for reducing the adverse effects of temperature stress on plants: A review. Environ. Exp. Bot. 35: 251-258.

Meehl GA, Stocker TF, Collins WD, Friedlingstein P, Gaye T, Gregory JM, Kitoh A, Knutti R, Murphy JM, Noda A et al. 2007. Global climate projections. Climate Change 2007: The Physical Science Basis, S. Solomon et al. Eds. Cambridge University Press, 747845. 
Memmott J, Craze PG, Waser NM, Price MV 2007. Global warming and the disruption of plant-pollinator interactions. Ecology letters 10(8): 710-717.

Mevi Schütz J, Erhardt A. 2003. Amino Acids in Nectar Enhance Butterfly Fecundity: A Long Awaited Link. The American Naturalist 165(4): 411-419.

Mitchell RJ, Karron JD, Holmquist KG, Bell JM. 2004. The influence of Mimulus ringens floral display size on pollinator visitation patterns. Functional Ecology 18: 116-124.

New B, Duthion C, Turc O. 1994. Phenological response of pea to water stress during reproductive development. Crop science 34(1): 141-146.

Nord EC, Lynch JP. 2009. Plant phenology: a critical controller of soil resource acquisition. Journal of Experimental Botany 60(7): 1927-1937.

Pacini E, Nepi M. 2007. Nectar production and presentation. In: Nicolson S.W., Nepi M., Pacini E. (eds) Nectaries and Nectar. Springer, Dordrecht.

Parachnowitsch AL, Kessler A. 2010. Pollinators exert natural selection on flower size and floral display in Penstemon digitalis. New Phytol. 188(2): 393-402.

Perfors T, Harte J, Alter SE. 2003. Enhanced growth of sagebrush (Artemisia tridentata) in response to manipulated ecosystem warming. Global Change Biology 9: 736-742.

Petanidou T, Van Laere A, Ellis WN, Smets E. 2006. What shapes amino acid and sugar composition in Mediterranean floral nectars? Oikos 115(1): 155-169.

Pyke GH. 1984. Optimal Foraging Theory: A Critical Review. Annual Review of Ecology and Systematics 15(1): 523-575.

Quemada M, Gabriel JL. 2016. Approaches for increasing nitrogen and water use efficiency simultaneously. Global Food Security 9: 29-35.

R Core Team 2020. R: A language and environment for statistical computing. R Foundation for Statistical Computing, Vienna, Austria. URL: https://www.R-project.org/.

Rafferty NE, Ives AR. 2011. Effects of experimental shifts in flowering phenology on plantpollinator interactions. Ecology Letters 14(1): 69-74.

Reverté S, Retana J, Gómez JM, Bosch J. 2016. Pollinators show flower colour preferences but flowers with similar colours do not attract similar pollinators. Annals of Botany 118(2): 249-257.

Roldán-Serrano AS, Guerra-Sanz JM. 2005. Reward attractions of zucchini flowers (Cucurbita pepo L.) to bumblebees (Bombus terrestris L.). Eur. J. Hortic. Sci. 70: 23-28.

Rustad LE. 2008. The response of terrestrial ecosystems to global climate change: towards an integrated approach. Sci. Total Environ. 404: 222-235.

Scaven VL, Rafferty NE. 2013. Physiological effects of climate warming on flowering plants and insect pollinators and potential consequences for their interactions, Current Zoology 59(3): 418-426. 
Schmidt K, Filep R, Orosz-Kovács Z, Farkas A. 2015. Patterns of nectar and pollen presentation influence the attractiveness of four raspberry and blackberry cultivars to pollinators. J. Hortic. Sci. Biotechnol. 90: 47-56.

Schweiger O, Biesmeijer JC, Bommarco R, Hickler T, Hulme PE. 2010. Multiple stressors on biotic interactions: How climate change and alien species interact to affect pollination. Biol. Rev. (85): 777-795.

Scott-Wendt J, Chase RG, Hossner LR. 1988. Soil chemical variability in sandy Ustalfs in semi-arid Niger, West Africa Soil Science (June): 414.

Serhatli U, Yucesan CA. 2020. Optimal Agricultural Supply Planning Under Climate Change: The Impact of Extreme Events (March 03, 2020). INSEAD Working Paper No. 2020/13/TOM, Available at SSRN: https://ssrn.com/abstract=3218879 or,

http://dx.doi.org/10.2139/ssrn.3218879

Snider JL, Oosterhuis DM. 2011. How does timing, duration, and severity of heat stress influence pollen pistil interactions in angiosperms? Plant Signaling \& Behavior 6(7): 930- 933.

Takkis K, Tscheulin T, Tsalkatis P, Petanidou T. 2015. Climate change reduces nectar secretion in two common Mediterranean plants. AoB Plants 7: 111.

Vasseur DA, DeLong JP, Gilbert B, Greig HS, Harley CDG, McCann KS, Savage V, Tunney TD, O’Connor MI. 2014. Increased temperature variation poses a greater risk to species than climate warming. Proceedings of the Royal Society B: Biological Sciences 281(1779): 2013-2612.

Villarreal AG, Freeman CE. 1990. Effects of temperature and water stress on some floral nectar characteristics in Ipomopsis longiflora (Polemoniaceae) under controlled conditions. Bot. Gaz.151: 5-9.

Wyatt R, Broyles SD, Derda GS. 1992. Environmental influences on nectar production in milkweeds (Asclepias syriaca and A. exaltata). American Journal of Botany 79: 636-642.

Zeppel MJB, Wilks J, Lewis JD. 2014. Impacts of extreme precipitation and seasonal changes in precipitation on plants. Biogeosciences 11: 3083-3093.

Zimmermann M, Pyke GH. 1988. Reproduction in Polemonium: assessing the factors limiting seed set. American Naturalist 131: 723-738. 